\title{
Acute Toxicity of Organophosphate Insecticide Dichlorvos to Fingerlings of Cyprinus carpio (Linnaeus, 1758)
}

\author{
B. Laxmi ${ }^{1}$, K. Madhavi ${ }^{1 *}$, K. Dhanapal ${ }^{2}$, Adnan Amin ${ }^{1}$, N. Jesintha ${ }^{3}$, \\ R. R. Anupama ${ }^{1}$ and C. Prabhanjan Kumar Reddy ${ }^{1}$
}

${ }^{1}$ Department of Aquatic Environment Management, ${ }^{2}$ Department of Fish Processing Technology, ${ }^{3}$ Department of Fisheries Resource Management, College of Fishery Science, Muthukur, Nellore District, Andhra Pradesh, India

*Corresponding author

\section{A B S T R A C T}

\section{Keywords}

Organophosphates, Dichlovos, $\mathrm{LC}_{50}$

Article Info

Accepted:

10 September 2020

Available Online:

10 October 2020
Toxicological effects of pesticides on aquatic organisms are very important, especially when these animals are serving as functional foods with respect to human consumption. Dichlorvos, one of the extensively used insecticides was investigated in the present study for acute toxicity following static bioassay method and fingerling common carp (Cyprinus carpio) was selected as test specimen. The 96 hour $\mathrm{LC}_{50}$ value was found to be $21.11 \mathrm{ppm}$. Impact of test conditions (hardness of water) on $\mathrm{LC}_{50}$ value was evidenced in the present research, water hardness has resulted in decreased toxic potential of test substance, there by increased $\mathrm{LC}_{50}$ value.

\section{Introduction}

The contamination of surface water with pesticides is an ongoing concern worldwide. These very substances that have been developed for various anthropologic benefits eventually led to the realization that these chemicals, beneficial on application, has transcended to cause serious threats to the ecosystem. Due to the widespread use of pesticides, their residues are detected in various environmental matrices, like soil, water and air. Pesticide residues reach the water body through direct runoff, leaching, careless disposal of empty containers, equipment washing etc. The amount of pesticides lost from agricultural fields and transported to surface waters depends on several factors, including soil characteristics, topography, weather, agricultural practices, and chemical and environmental properties of individual pesticides (Leonard, 1990).

Sorption and desorption processes, degradation, transport and their solubility are all important factors that decide the fate of pesticides in the surrounding medium. Due to the residual effects of pesticides, important 
organs like kidney, liver, gills, stomach, brain, muscle and genital organs are damaged in fish exposed to pesticide (Odiete, 1999). It has been recognized, however, that the sensitivity of fish to pesticide varies with species, size and age, it is also known that pesticide toxicity to fish is affected by water hardness and $\mathrm{pH}$.

Furthermore, species may differ in the uptake, accumulation, distribution, metabolism and excretion of chemicals. Bioaccumulation rate of pesticides in fish depends on the species, life stages, the amount of fat deposits in different tissues and diet of fish, chemical and physical properties of pesticides etc.

There was a shift in the types of insecticides used in the mid 1960's from the organochlorine to the less stable organophosphate and carbonate classes (Henry, 1984).

The shift from organochlorines to organophosphates has resulted into increased occurrence of organophosphates into water bodies causing acute and chronic toxicity to fish fauna (Rao et al., 2005; Velmurugan et al., 2007). Their high insecticidal properties, low mammalian toxicity, less persistence and rapid biodegradability in the environment made them as one of the most preferred pesticides for application. These very pesticides may reach other ecological compartments as lakes and rivers through rains and wind, affecting many other organisms away from the primary target.

Toxicity tests become imperative to estimate potential hazards as part of risk assessment protocols in ecological sustainability studies. The selection of organisms for toxicity test is mainly based on certain criteria like, its ecological status, position within food chain, suitability for laboratory studies, genetically stable \& uniform populations and adequate back ground data on the organism.

In the science of aquatic toxicology, fish play an important role in toxicity testing and hazard evaluation, as do the white rat and guinea pig in mammalian toxicology (Anon, 1972), especially teleost fish may be a good indicator of pollution as their biochemical responses are almost similar to that of mammals (Banaee et al., 2008).

\section{Materials and Methods}

Testspecies selection, collection and conditioning

Common carp has been selected as test species due to its ready availability throughout the year, ease of maintenance, convenience for testing and moreover is an economically important edible fish, having great commercial value and the same species has also been recommended for bioassay experiments by 'Organization for Economic Cooperation and Development (OECD, 1992). It forms an important candidate species in carp poly-culture systems in India. The specimens were about 3-months old with an average body length of $5.7 \pm 0.60 \mathrm{~cm}$ and of body weights $2.1 \pm 0.45 \mathrm{~g}$.

Common carp fingerlings were collected from nearby fish farm and brought to the laboratory in plastic bags with sufficient air. Upon arrival at the laboratory, fishes were housed in FRP tanks of $1000 \mathrm{~L}$ capacity for 15 days to allow for acclimatization (under the following conditions) prior to pesticide exposure.

The fingerlings were fed twice in every 24 hours with dry pellet feed at the rate of $5 \%$ body weight per day and the excreta was siphoned out daily to prevent buildup of ammonia in the medium. 


\begin{tabular}{|l|c|l|}
\hline Light & $\mathbf{1}$ & $\mathbf{1 2}$ to $\mathbf{1 4}$ hours photoperiod daily \\
\hline Water & $:$ & Good quality tap water (it is completely free from chlorine) \\
\hline Temperature & $:$ & $32 \pm 2^{\circ} \mathrm{C}$ \\
\hline Salinity & $:$ & $1 \mathrm{ppt}$ \\
\hline pH & $:$ & $7.1 \pm 0.2$ \\
\hline Dissolved oxygen & $:$ & Aerated continuously, except at the time of feeding \\
\hline Alkalinity & $:$ & $220 \pm 18 \mathrm{ppm}$ \\
\hline Hardness & $:$ & $380 \pm 26 \mathrm{ppm}$ \\
\hline
\end{tabular}

All the abovementioned water quality parameters were analyzed following standard methods as per APHA, 2005.

\section{Test substance}

Dichlorvos (as commercial formulation Hyvap - dichlorvos, 76\% EC)

\section{Pesticide type: Insecticide}

CAS number: 62-73-7 (Pesticides can have more than one common name, trade name and chemical name. The CAS Registry Number (Chemical Abstracts Systematic names) is a single identifier aimed to remove any ambiguity arising from the various nomenclatures.

Dichlorvos is poisonous if swallowed, inhaled, or absorbed through the skin; therefore, it acts as a contact and stomach poison (WHO, 1985). Because dichlorvos is one of the more volatile pesticides among organophosphates, it has been used primarily for its fumigant action (Cremlyn, 1978). It is effective in controlling nuisance pests (e.g., caterpillars, flies, mosquitoes, and cockroaches) in and around domestic dwellings, stored products, commercial transportation vehicles, and livestock buildings. Dichlorvos also has been added directly to water to control parasites in intensive fish farming (WHO, 1989).

Preparation of stock solution- As 1gm dichlorvos is approximately equal to $0.76 \mathrm{~mL}$, so as to prepare $1000 \mathrm{ppm}$ stock solution, we need to have $0.76 \mathrm{~mL}$ of dichlorvos in $1000 \mathrm{~mL}$ of the solution. As, Hyvap consisted of only $76 \%$ Effective Concentration (EC) of dichlorvos, $1 \mathrm{~mL}$ of hyvap contains dichlorvos of $0.76 \mathrm{~mL}$. So, $1 \mathrm{~mL}$ of Hyvap was added to tap water and finally made it to $1 \mathrm{~L}$, so as to have the stock solution of 1000 ppm dichlorvos.

Test solutions - Test solutions of chosen concentrations were prepared by diluting stock solution.

\section{Acute toxicity test}

The toxicity of an insecticide to an aquatic organism is usually expressed in terms of $\mathrm{LC}_{50}$. This value represents the amount of a toxicant either in the form of concentration $\left(\mathrm{LC}_{50}\right)$, which kills $50 \%$ of the population of the test animal with in a fixed period of time (Finney, 1971).

Following acclimation, only healthy fish that were not diseased, as determined by general appearance (colour, skin luster, eyes and behavior) were selected for the study. The fingerlings were starved for 24 hours prior to the selection of individuals for the experiment to avoid any influence of differential feeding. While transferring and handling of fishes, care was taken to ensure that the test fishes were least stressed. Fishes were exposed to the test substance for a period of 96 hours. Mortalities were recorded at 24, 48, 72 and 96 hours and the concentration at which $50 \%$ 
mortality of the test fishes occurred $\left(\mathrm{LC}_{50}\right)$ were calculated.

\section{Experimental design}

Tests were conducted in FRP tanks of $40 \mathrm{~L}$ capacity and filled with $20 \mathrm{~L}$ of tap water. Static bioassay test was conducted in duplicate for each concentration of pesticide with 10 animals per replicate and appropriate controls were also maintained for a period of 96 hours under the laboratory conditions. Experimental insecticide (dichlorvos) concentrations were calculated according to the active ingredient percentage of the commercial formulation. The expiry date of the test substance checked prior to initiation of the treatment was found suitable for the exposure. Precautions were taken to avoid contamination of the control.

We first carried out range finding acute test (limit tests) with dichlorvos concentrations of $1 \mathrm{ppm}, 5 \mathrm{ppm}, 10 \mathrm{ppm}, 20 \mathrm{ppm}$ and $25 \mathrm{ppm}$ to pinpoint exposure concentrations for the definitive acute test. Based on the results of this 'wide range test', a definitive test was carried out in 'narrow range' between $15 \mathrm{ppm}$ and $25 \mathrm{ppm}$ concentrations spaced at an interval of $1 \mathrm{ppm}$, so as to generate data, which would be necessary to arrive at $\mathrm{LC}_{50}$ concentration of the test substance (dichlorvos).

Accordingly ten acclimated fingerlings (A loading rate of $1.1 \mathrm{~g} / \mathrm{L}$ was followed) were placed in each replicate with dichlorvos concentrations $0 \mathrm{mg} / \mathrm{L}$ (Control), 15, 16, 17, $18,19,20,21,22,23,24$ and $25 \mathrm{ppm}$ for 96 hours and the mortality or responsiveness were recorded specifically at $24,48,72$ and 96 hours after commencement of exposure. Fishes were considered dead when there was no response even to a gentle touch of fish catching net and dead fishes were removed instantly. The data obtained from the experiment was processed by 'Probit analysis' (Finney, 1971) for determination of median lethal concentration $\left(\mathrm{LC}_{50}\right)$.

\section{Results and Discussion}

Acute toxicity test was performed following 'static bioassay' method with two replicates, so as to determine $\mathrm{LC}_{50}$ (median lethal concentration) value of dichlorvos to fingerling common carp (active, healthy, disease free) under controlled laboratory conditions (Light: 12 to 14 hours photoperiod; Temperature: $32 \pm 2^{\circ} \mathrm{C}$; $\mathrm{pH}$ : $7.1 \pm 0.2$; Salinity: 1 ppt; Dissolved Oxygen: $8.0 \pm 0.6$ ppm; Alkalinity $220 \pm 18$ ppm and Hardness: $380 \pm 26$ ppm).

Mortality pattern of common carp fingerlings in different concentrations of 'dichlorvos' during the test tenure (96 hours) is presented in table 1. Percentage mortalities and 'median lethal concentration $\left(\mathrm{LC}_{50}\right)$ on logarithmic scale was depicted graphically (Fig. $1 \& 2$, respectively).

Acute toxicity study revealed a strong negative effect of dichlorvos on the survival of fingerlings with increasing pesticide concentration there by exhibited dosedependent survival and concentration graded lethality. In the present study, the median lethal concentration (acute toxicity) i.e., $\mathrm{LC}_{50}$ value of dichlorvos to fingerling common carp was found (through probit analysis) to be $21.11 \mathrm{ppm}$.

The $\mathrm{LC}_{50}$ observed in the present research is somewhat higher compared to the earlier works of dichlorvos on fingerling common carp. Though the pesticide, fish species, size of the fish seemed to be common to earlier works, as a multitude of factors like genetic properties, health status of test specimen, physico-chemical parameters of water (medium of acclimatization and tests), 
exposure technique followed, preparation of test solutions of required concentration with due consideration of EC\% (effective concentration) of active ingredient present in the commercial formulation used etc. influences the $\mathrm{LC}_{50}$ value, one or couple of these factors might have resulted in higher $\mathrm{LC}_{50}$ value. Among the different factors enlisted above, it has been supposed that, water hardness $(380 \pm 26 \mathrm{ppm})$ might have played a major role in elevating the $\mathrm{LC}_{50}$ value by reducing the toxicity potential of the test substance (dichlorvos) in the present study, besides good health status of test specimen (fingerling common carp). Under hard water conditions, it has been already proved that, the binding of pesticides with the hardness creates molecules which cannot enter into the test specimen, or which enter at a much slower rate, or which precipitate out of solution.

Table.1 Mortality pattern of common carp fingerlings in different concentrations of 'dichlorvos' during the test tenure (96 hours)

\begin{tabular}{|c|c|c|c|c|}
\hline $\begin{array}{c}\text { Conc. of Dichlorvos } \\
\text { (ppm) }\end{array}$ & Log Conc. & $\begin{array}{c}\text { Total No. of fish } \\
\text { expose (10 } \\
\text { Nos./replicate) }\end{array}$ & $\begin{array}{c}\text { Mean } \\
\text { Mortality }(\%)\end{array}$ & Probit value \\
\hline $\mathbf{1 5 . 0}$ & 1.18 & 20 & 0 & - \\
\hline $\mathbf{1 6 . 0}$ & 1.20 & 20 & 0 & - \\
\hline $\mathbf{1 7 . 0}$ & 1.23 & 20 & 10 & 3.72 \\
\hline $\mathbf{1 8 . 0}$ & 1.25 & 20 & 20 & 4.16 \\
\hline $\mathbf{1 9 . 0}$ & 1.28 & 20 & 30 & 4.48 \\
\hline $\mathbf{2 0 . 0}$ & 1.30 & 20 & 45 & 4.87 \\
\hline $\mathbf{2 1 . 0}$ & 1.32 & 20 & 45 & 4.87 \\
\hline $\mathbf{2 2 . 0}$ & 1.34 & 20 & 55 & 5.13 \\
\hline $\mathbf{2 3 . 0}$ & 1.36 & 20 & 70 & 5.62 \\
\hline $\mathbf{2 4 . 0}$ & 1.38 & 20 & 85 & 6.04 \\
\hline $\mathbf{2 5 . 0}$ & 1.39 & 20 & 100 & - \\
\hline
\end{tabular}

Table.2 Transformation of percentages to probits

\begin{tabular}{|c|c|c|c|c|c|c|c|c|c|c|}
\hline$\stackrel{0 \%}{\circ}$ & 0 & 1 & 2 & 3 & 4 & 6 & 6 & $\tau$ & 8 & D \\
\hline 0 & - & 2.67 & 2.05 & 3.12 & 3,25 & 3.30 & 3.45 & 3.52 & 3.59 & 3.06 \\
\hline 10 & 3.72 & 3.77 & 3.82 & 3.87 & 3.08 & 3.00 & 4.01 & 4.05 & 4.08 & 4.12 \\
\hline 20 & 4.16 & 4.19 & 4.23 & 4.26 & 4.28 & 4.33 & 4.30 & 4.38 & 4.42 & 4.46 \\
\hline 30 & 4.48 & 4.00 & 4.63 & 4.60 & 4.69 & 4.61 & 4.64 & 4.67 & 4.69 & 4.72 \\
\hline 40 & 4.76 & 4.77 & 4.80 & 4.82 & 4.85 & 4.87 & 4.90 & 4.92 & 4.95 & 4.97 \\
\hline 50 & 0.00 & 6.03 & 6.05 & 5.08 & 5.10 & 5.13 & 5.15 & 5.18 & 5.20 & 6.23 \\
\hline 60 & 0.26 & 0.28 & 6.31 & 6.83 & 5.36 & 5.39 & 5.41 & 5,44 & 5.47 & 5.50 \\
\hline 70 & 5.62 & 5.65 & 5.68 & 5.61 & 5.64 & 5.67 & 5.71 & 5.76 & 5.77 & 6.81 \\
\hline so & 6.84 & 0.88 & 6.92 & 5.95 & 5.99 & 0.04 & 6.08 & 6.13 & 0.18 & 0.23 \\
\hline 00 & 0. 28 & 0.34 & Q.41 & 6.48 & 6.05 & G.64 & 6.75 & 0.88 & 7.05 & 7.33 \\
\hline- & $0.0^{\circ}$ & 0.1 & 0.2 & 0.3 & 0.4 & 0.6 & 0.6 & 0.7 & 0.8 & 0.9 \\
\hline 99 & 7.33 & 7.37 & 7.41 & 7.40 & 7.61 & 7.58 & 7.65 & 7.75 & 7.88 & 8.09 \\
\hline
\end{tabular}


Table.3 Summary output of ANOVA

\begin{tabular}{|c|c|c|c|c|c|c|c|c|}
\hline $\begin{array}{l}\text { SUMMARY } \\
\text { OUTPUT }\end{array}$ & & & & & & & & \\
\hline \multicolumn{9}{|c|}{ Regression Statistics } \\
\hline Multiple R & 0.9012229 & & & & & & & \\
\hline R Square & 0.812202715 & & & & & & & \\
\hline Adjusted R Square & 0.788728055 & & & & & & & \\
\hline Standard Error & 0.990432499 & & & & & & & \\
\hline Observations & 10 & & & & & & & \\
\hline \multicolumn{9}{|l|}{ ANOVA } \\
\hline & $d f$ & SS & $M S$ & $F$ & $\begin{array}{c}\text { Significance } \\
F\end{array}$ & & & \\
\hline Regression & 1 & 33.94023772 & 33.94024 & 34.59912 & 0.0003691 & & & \\
\hline Residual & 8 & 7.847652281 & 0.980957 & & & & & \\
\hline \multirow[t]{2}{*}{ Total } & 9 & 41.78789 & & & & & & \\
\hline & Coefficients & $\begin{array}{l}\text { Standard } \\
\text { Error }\end{array}$ & $t$ Stat & $P$-value & Lower 95\% & $\begin{array}{l}\text { Upper } \\
95 \%\end{array}$ & $\begin{array}{l}\text { Lower } \\
95.0 \%\end{array}$ & $\begin{array}{l}\text { Upper } \\
95.0 \%\end{array}$ \\
\hline Intercept & -32.56286166 & 6.20499038 & -5.24785 & 0.000776 & -46.8716 & $18.254128^{-}$ & -46.871595 & -18.2541282 \\
\hline X Variable 1 & 28.36213695 & 4.821768908 & 5.882102 & 0.000369 & 17.243118 & 39.481156 & 17.2431179 & 39.48115598 \\
\hline
\end{tabular}

Fig.1 Percentage mortalities of common carp exposed to different concentrations of Dichlorvos during 96 hours test tenure

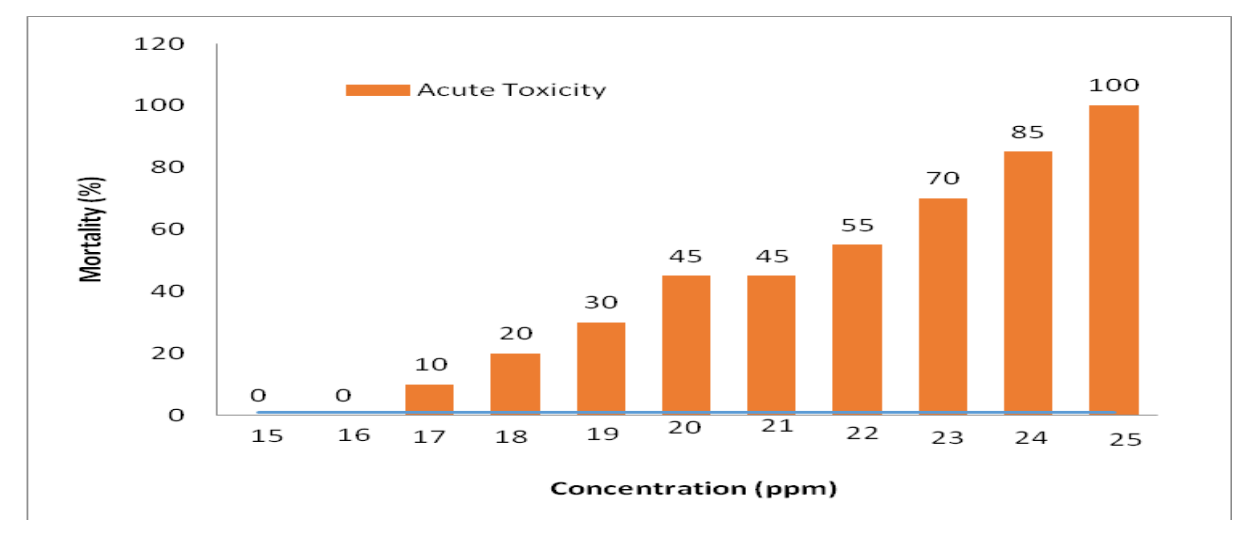

Fig.2. Graphical representation of $96 \mathrm{~h} \mathrm{LC}_{50}$ of 'dichlorvos' to common carp fingerlings

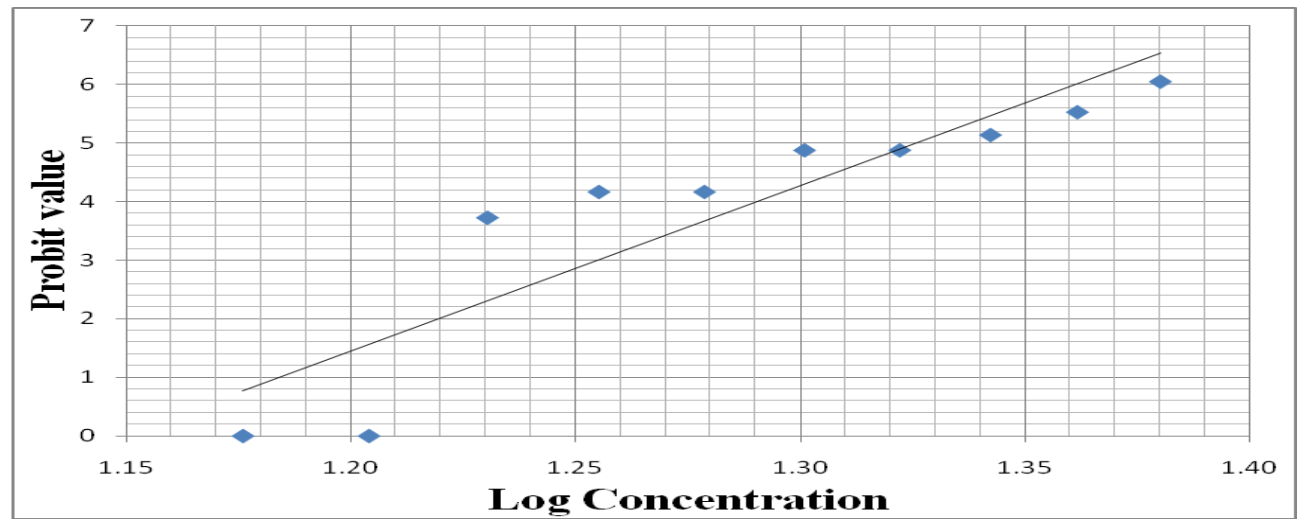




\section{Validity of the test}

Our test is valid (vide OECD Guidelines, 1992) as the mortality in the control group not exceeded $10 \%$ by the end of 96 hours. The findings of following works [a): dichlorvos on others b) impact of hardness on LC50 value] are in support of the present study

a). Gupta et al., (2008) while investigating on the acute toxicity of dichlorvos in relation to selected hardness for freshwater zooplankters (Moina, Daphnia and Cyclops) revealed that, dichlorvos is relatively highly toxic at low water hardness $(275 \mathrm{mg} / \mathrm{L})$ compared to high water hardness $(540 \mathrm{mg} / \mathrm{L})$ there by observed nearly $100 \%$ increase in the $\mathrm{LC}_{50}$ values obtained under hard water conditions. Srivastava et al., (2012) reported 96 hour $\mathrm{LC}_{50}$ value of 'dichlorvos' to Cirrhinusmrigala during a static-renewal test as $20.72 \mathrm{mg} / \mathrm{L}$.

b). Mungkung et al., (2001) observed a statistically significant increase in the median lethal concentration $\left(\mathrm{LC}_{50}\right)$ of cadmium to Puntius goninotus, with increasing hardness (soft water-4.17 ppm; moderately hard water-4.35 ppm; hard water-5.05 ppm). Dutta et al., (2002) noticed a significant reduction (nearly fivefold increase in $\mathrm{LC}_{50}$ value in hard water compared to soft water) in the toxicity of 'deltamethrin' to 'common carp' with increasing hardness of water, and they opined that, the observed lowered toxicity of deltamethrin under hard water conditions might be due to change in the chemistry of biotic receptor sites which might have reduced the permeability of deltamethrin. Gautam and Gupta (2008) reported that, the sensitivity of juvenile Poecilia to 'cypermethrin' was decreased considerably with the increase in hardness of water. Kiyani et al., (2013) reported a 38 fold decrease in the toxicity of $\mathrm{Cu}$ and a 264 fold decrease in the toxicity of $\mathrm{Zn}$ to Gambusia holbrooki under hard water conditions (350 $\mathrm{mg} / \mathrm{L})$.

\section{Statistical Analysis}

Regression analysis was carried out to find out median lethal concentration $\left(\mathrm{LC}_{50}\right)$ from the above data following 'probit analysis' method as per Finney (1971) percentage mortality was converted to probit value using table-2 and summary output of ANOVA was represented in table-3.

Regression equation $\mathrm{Y}=\mathrm{a}(\mathrm{X})+\mathrm{b}$, incorporating $\mathrm{a}$ and $\mathrm{b}$ values in this equation and considering $\mathrm{Y}$ value as 5.0 (as the probit conversion for $50 \%$ mortality is 5.0 )

Then, $5.0=28.36(\mathrm{X})+(-32.56)$

$5.0=28.36(\mathrm{X})-32.56$

$28.36(X)=5.0+32.56$

$\mathrm{X}=(37.56) /(28.36)=1.3244$

So, median lethal concentration $\mathrm{LC}_{50}=$ anti $\log$. $(1.3244)=21.11 \mathrm{ppm}$

In conclusion this study can be used to help the environmental management agency to enhance public awareness in order to prevent indiscriminate use of pesticides and also to assure the effective use of these pesticides also for regulatory purposes.

\section{References}

Anon, 1972. EPA bans most DDT uses; readies lead action. Environmental Science and Technology, 6: 675.

APHA, 2005. Standard Methods for the Examination of Water and Waste Water, American Public Health Association. Washington, DC.

Banaee, M., Mirvagefei, A.R., Rafei, G.R. and Majazi A. B., 2008. Effect of sub-lethal diazinon concentrations on blood plasma biochemistry. International Journal of Environmental Research, 2: 189-198.

Cremlyn, R., 1978. In: Pesticides-Preparation and mode of action. John \& Sons. pp.141-142.

Dutta, S., Kent, Y., Shaht, P. S. and Das R. C. 
2002. Effect of some environmental factors on the acute toxicity of deltamethrin to common carp: a laboratory study under aerobic condition. Journal of the Indian Fisheries Association, 31-40.

Finney, D.J., 1971. Probit analysis. 3rd edn. Cambridge University Press, London. pp: 508-510.

Gautam, P.P. and Gupta, A.K., 2008. Toxicity of cypermethrin to the juveniles of freshwater fish Poecilia reticulata (Peters) in relation to selected environmental variables. Indian Journal of Natural Products and Resources, 7: 314-319.

Gupta, A. K., Verma, G. P. and Jain, K. L., 2008. Acute toxicity of organophosphate insecticide, dichlorvos in relation to selected water hardness for the freshwater zooplankters. J. Environ. Biol., 29(6), 837-839.

Henry, C. 1984. Organochlorine residues in a Jamaican river and uptake and elimination of dieldrin by the shrimp Machrobrachiumfaustinum de Saussure ( Msc thesis). University of the west indies, Mona, Jamaica.

Kiyani, V., Hosynzadeh, M. and Ebrahimpour, M., 2013. Investigation acute toxicity some of heavy metals at different water hardness. International journal of Advanced Biological and Biomedical Research, 134-142.

Leonard, R.A., 1990. Movement of pesticides into surface waters. Pesticides in the soil environment: processes, impacts, and modeling, 303-349.

Mungkung, R., Upatham, E.S., Pokethitiyook, P., Kruatrachue, M. and Panichajakul, C.
2001. Effects of humic acid and water hardness on acute toxicity and accumulation of cadmium in the freshwater fish (Puntius gonionotus Bleeker). Science Asia., 157-164.

Odiete, W.O., 1999. Environmental Physiology of animals and pollution. Diversified Resources Ltd, Lagos., Pp. 193 - 246.

OECD (Organization for Economic Cooperation and Development) (1992). OECD guidelines for testing of chemicals. Fish, Acute Toxicity Test 203:1-9.

Rao, J.V., Begum, G., Pallela, R., Usman, P.K. and Rao, R.N., 2005. Changes in behavior and brain acetylcholinesterase activity in mosquito fish, Gambusia affinis in response to the sub-lethal exposure to chlorpyrifos. International Journal of Environmental Research and public health, 2: 478-483.

Srivastava, N., Rai, A.K., Kumari, U., Mittal, S. and Mittal, A.K., 2012. Behavioural dysfunctions in relation to the toxicity of 'NUVAN®', an organophosphorus insecticide in an Indian major carp, Cirrhinusmrigala. Res. Env. Life Sci.,5(4): 245-250.

Velmurugan, B., Selvanayagam, M., Cengiz, E.I. and Unlu, E., 2007. The effects of monocrotophos to different tissues of freshwater fish Cirrhinusmrigala. Bulletin of environmental contamination and toxicology, 78: 450-454.

WHO (1985).Specifcations for Pesticides Used in Public Health, 6th ed., Geneva, pp. 163-168.

WHO, 1989. Dichlolvos (Environmental Health Criteria 79), Geneva, Switzerland.

\section{How to cite this article:}

Laxmi, B., K. Madhavi, K. Dhanapal, Adnan Amin, N. Jesintha, R. R. Anupama and Prabhanjan Kumar Reddy, C. 2020. Acute Toxicity of Organophosphate Insecticide Dichlorvos to Fingerlings of Cyprinus carpio (Linnaeus, 1758). Int.J.Curr.Microbiol.App.Sci. 9(10): 12391246. doi: https://doi.org/10.20546/ijcmas.2020.910.149 